\title{
Present Status of Medical Waste Disposal System in Chittagong Medical College Hospital (CMCH), Chittagong
}

\author{
Md. Tarikul Islam \\ (Scientific Officer, Bangladesh Oceanographic Research Institute, Ramu, Cox's Bazar, Bangladesh)
}

\begin{abstract}
Medical wastes are highly infectious and hazardous. It may carry the germs of dreadful diseases like hepatitis $B$ and $C$ (jaundice), and HIV/AIDS. It contains toxic chemicals and hazardous materials from several diagnostic and treatment processes. The improper disposal of Medical waste in the CMCH poses a high health risk to humans as well as the environment. This study was carried out from July 2014 to September 2014 to know the characteristics of Medical waste and present disposal system in CMCH. Categorization of medical wastes included sharps, pathological waste, pharmaceutical waste and chemical waste. Sharps were counted in number and pathological wastes were assessed in weight $(\mathrm{kg})$. The most frequently discharged component of sharps was observed as ampoules and vials, which comprised about $45.08 \%$, syringe and needles occupied about $42.20 \%$, infusion sets with saline bags occupied about $10.71 \%$ and about $2.01 \%$ pathological waste. The bacteriological quality of discharged wastes and the soil of the disposal ground were evaluated on the basis of bacterial indicator such as E.coli count, occurrence of Salmonella spp. And Vibrio cholera which exceeded the standard level suggested by WHO for standard of soil and water. The results revealed that the present waste disposal system was unhygienic and unsafe. The knowledge level of hospital staff on the harmful impacts of improper waste disposal was also very low. The need for raising awareness, improving waste handling and disposal system, and implementing laws and regulations regarding Medical waste management are recommended.
\end{abstract}

Keywords: CMCH, Sharps, Pathology, Disposal, Bacterial Load

\section{Introduction}

Bangladesh is a densely populated country, which has limited health facility for the people. Chittagong Medical College Hospital $(\mathrm{CMCH})$ is a tertiary level hospital, which provides wide range of treatment to the patients. It is sometimes reported that patient bearing hepatitis, cancer, HIV and many others are admitted to the hospital. So, the wastes coming from those patients bear highly hazards germ which can easily be transmitted to others through syringe, needle or by other medium. Because there is no proper assessment or characterization of the wastes of this hospital and for the relevant causes safe management system of the wastes is partially absent here. The wastes are also known to clog sewers and open drains, encroach roadways, diminish landscape aesthetics and give unpleasant odours and dust. Little regard is given to the location of the dump and many are found next to residential areas. There has been little research done on Medical waste disposal in Bangladesh. A survey, conducted by Rashid et. al. (1996) on Medical Waste Disposal in Dhaka City, found that the government hospitals placed all waste in open dustbin.

Kazi (1997) also conducted a study on hospital waste in Chittagong and recommended several steps to improve hospital waste management in Bangladesh. Akter et al. (1999) conducted a study on Medical waste disposal at BRAC Health Centres. Medical waste disposal systems in both the government hospitals and private clinics were severely unhygienic and unsafe. In general, hospital waste refers to all waste, biological and nonbiological, that is discarded and not intended for further use (Burke, E.L.J. Environment Health 1994, 56 (9), 11-14). National Environmental Research Institute (1997) stated the average composition of hospital waste, which showed percentage of different components in the waste. According to Chih-Shan \& Fu-Tien (1993), composition of waste from hospital in Taiwan and China shows that among the total component present in the medical waste, paper occupies $16 \%$, plastics $50 \%$, textiles $10 \%$, food waste $21 \%$, sharps $0.5 \%$ and others $1.5 \%$.

Askarian et al, (2004) explain the type and nature of hospital wastes generated from private hospitals in Fars province in Iran and also describe the existing management systems of the generated wastes in hospitals. According to Mato et. al. (1999), the hazardous waste includes pathological, infectious, sharps and chemical wastes and are normally produced in labour wards, operation theatres, laboratories, etc. According to Patil and Pokhrel (2004) described the biomedical solid waste management in an Indian hospital. Karademir (2004) provides a report on the health risk assessment of $\mathrm{PCDD} / \mathrm{F}$ emissions from a hazardous and medical waste incinerator in Turkey.

Dhaka Medical College Hospital (DMCH) has the capacity for 1400 beds and about 500 floor patient (Ahmed, 2000). The hospital provides emergency treatment to about 250-300 patients daily, surgical treatment (major and minor operations) to about 3900-4000 patients per day from various departments and wards, and 
outdoor advice to about 1000-1200 in a day. According to the BCAS, (1997), in collaboration with Asia Foundation undertook a study on "Hospital Environmental Management" with the aiming of investigation and improvement of safe handling and disposal of hospital waste in the country (BCAS, 1997). .

The rapid increase of hospitals, clinics, diagnostic laboratories etc in Chittagong city exerts a tremendous impact on human health ecology. More than 300 clinics, hospitals and diagnostics centers exist in the Chittagong City Corporation (CCC). These facilities generate an estimated 100 tons of waste a day (Lawson, 2010). In a report from the World Bank (2009), only 10-25 percent of the hospital wastes are infectious or hazardous. The amount of such hazardous waste is quite small in figure and until recently this is not handled properly (WHO, 2010). The prevalence of diseases that may be transmitted by hospital wastes is alarming in Bangladesh. There is evidence of hepatitis B infection among 10 percent of children (5-10 age group) and 30 percent adults. About 5 per cent of the total population in Bangladesh is thought to suffer from chronic hepatitis B infection. Although cases of HIV/AIDS is low in Bangladesh (about 15,000 cases estimated in 2009) in comparison to neighboring countries, nevertheless the numbers are rising (Waste Concern, 2011). The safe disposal of Medical waste has been ignored in Bangladesh. Medical waste is a source of contamination and pollution to both humans and the environment.

Medical waste is capable of causing diseases and illnesses to people, either through direct contact or indirectly by contaminating soil, groundwater, surface water and air. Wind from these dumps can also carry pathogens and hazardous materials. Where domestic animals are allowed to graze in open dumps, there is a risk of reintroducing pathogenic microorganisms into human body through food chain. Medical waste therefore, poses a risk to individuals, communities, and the environment if not carefully handled.

\section{Background of the study area}

Chittagong Medical College Hospital $(\mathrm{CMCH})$ has been selected as the study area to assess the medical waste disposal, its fate and to develop a management system. It is a tertiary level hospital in the country, possessing 1,010 beds. Patients having different types of disease get admission here, and in the course of treatment dispose huge amount of wastes carrying infectious agents. Chittagong Medical College Hospital was first established as the name by "Chittagong General Hospital" with 200 beds over a hilltop at the downtown Anderkilla, overlooking the river Karnafully. The only modern hospital in this region that times the hospital served the population of Chittagong division. With the passage of time it was felt necessary to enhance healthcare facility as well as the quality of health care.

The Hospital was established at the present site in 1960 with only 12 beds and the out patient services. At that time the young hospital housed only the Department of Surgery and Gynecology and Obstetrics. The Hospital housed the Department of Medicine and allied specialties till 1969 and thereafter it remained affiliated with Chittagong Medical College Hospital as one of its teaching hospitals. The six stored CMCH was completed in 1969, which now accommodates all the clinical departments including all their subspecialties. The hospital which had a capacity of 500 beds initially, gradually increased its strength to 750 and finally to 1010 . It runs big out patients departments in the specialties like Medicine, Paediatrics, Psychiatry, Skin and Veneral diseases, Clinical Pathology, General Surgery, Ophthalmology, Obstetrics, Gynaecology, and Radiotherapy, Radiology and Dentistry with an average turnover in excess of 2250 person/day.

As years passed by, new treatment facilities kept being added and at present a Nuclear Medicine Centre for diagnostic and therapeutic purpose, a coronary unit, a Model Family Planning Centre, a burn unit, a centre for Extended program for Immunization (EPI), are among the many facilities available to the hospital in and out patients. Now 36 wards are reported to be present in this hospital. Among 1010 beds all are now essential and in many wards have a lot of extension beds than general beds.

Table-1: Location of the wards under study

\begin{tabular}{|c|l|c|c|c|c|}
\hline \multirow{2}{*}{ Serial No. } & \multirow{2}{*}{ Name of the ward } & \multicolumn{2}{|c|}{ Location } & \multirow{2}{*}{ Waste disposal system } \\
\cline { 2 - 5 } & & Floor & Ward & Bed & \\
\hline 1 & Skin and STD & Ground floor & $2 \mathrm{~B}$ & 20 & Direct dumping \\
\hline 2 & Radiotherapy & Ground floor & 6 & 24 & Direct dumping \\
\hline 3 & Paediatric Surgery & $1^{\text {st }}$ floor & IIB & 30 & Direct dumping \\
\hline 4 & Paediatric Medicine & $1^{\text {st }}$ floor & 9 & 116 & Direct dumping \\
\hline 5 & Nephrology & $2^{\text {nd }}$ floor & 17 & 24 & Direct dumping \\
\hline 6 & Surgery Unit-II & $4^{\text {th }}$ floor & 25 & 64 & Direct dumping \\
\hline 7 & Orthopaedic Surgery & $4^{\text {th }}$ floor & 26 & 88 & Direct dumping \\
\hline 8 & Surgery Unit-III & $4^{\text {th }}$ floor & 27 & 80 & Direct dumping \\
\hline 9 & Neuro Surgery & $4^{\text {th }}$ floor & 28 & 118 & Direct dumping \\
\hline 10 & Gynae & $5^{\text {th }}$ floor & 31 & 142 & Direct dumping \\
\hline 11 & Surgery unit-1 & $4^{\text {th }}$ floor & 24 & 54 & Direct dumping \\
\hline 12 & Antenatal \& Labor & $5^{\text {th }}$ floor & 33 & 96 & Direct dumping \\
\hline 13 & Postnatal ward & $5^{\text {th }}$ floor & 34 & 64 & Direct dumping \\
\hline 14 & Burn unit & $5^{\text {th }}$ floor & 36 & 34 & Direct dumping \\
\hline
\end{tabular}


The objectives of this study were-

\section{Objectives of the Study}

- To assess the different types of medical wastes which are generating from the $\mathrm{CMCH}$.

- $\quad$ To assess the waste disposal practice of $\mathrm{CMCH}$

- To assess the impacts of medical waste on environment as well as on human health

- On the basis of categories to recommend a management system of the wastes

\section{An overview of Medical waste}

Medical waste usually consists of clinical and non-clinical waste. Such pollutants can, therefore, be broadly classified into solid wastes, and liquid waste (wastewater). Both are important sources of environmental degradation and constitute a health hazard. For example the soil on which waste is dumped is a reservoir of microbial life. Also waste-contaminated water contains pathogenic micro-organisms which can cause many diseases.

Table-2 shows the types of medical waste according to Eigenheer \& Zanon. They classified medical waste according to their liquid and solid state.

Table 2.Types of medical wastes

\begin{tabular}{|c|c|}
\hline Type of Medical Waste & Typical examples \\
\hline \multicolumn{2}{|l|}{ Liquid Wastes } \\
\hline Biological waste & Blood, excrement, body fluid etc. \\
\hline Chemical waste & Solutions, inorganic salts etc. \\
\hline Radioactive waste & Wastes from radiology (iodine 125 , iodine 131 etc.) \\
\hline \multicolumn{2}{|l|}{ Solid Wastes } \\
\hline Clinical Waste & $\begin{array}{l}\text { Body fluid, drainage bags, blood collection tubes, vials, culture dishes, other types of } \\
\text { broken/unbroken glassware etc. }\end{array}$ \\
\hline Laboratory waste & $\begin{array}{l}\text { This includes chemicals used in the pathological laboratories, microbial cultures, and } \\
\text { clinical specimens, slide, culture dish, needle, syringes, as well as radioactive waste such } \\
\text { as iodine-125, iodine }-131 \text {, etc. }\end{array}$ \\
\hline
\end{tabular}

\subsection{Existing practice of Medical waste disposal}

Waste is collected from a small bowl or bin, kept under each bed in a hospital or a clinic and then either in a large plastic bag or a (plastic or metal) bucket. With a push cart these wastes are then carried to the nearest municipal bin for dumping. The municipal bins are either within hospital premises or outside the hospital. Waste from operation theaters, laboratories and hospital kitchens are also dumped into the same municipal bins. This waste is then collected from municipal bins by trucks and carried to the landfill area for final disposal.

Table-3 Items disposed off by different disposal system

\begin{tabular}{|c|c|c|c|c|c|}
\hline Sold & Burned & Buried & Dumped & $\begin{array}{l}\text { Container/Ba } \\
\text { sin }\end{array}$ & $\begin{array}{l}\text { Destroyed by } \\
\text { acid/Autoclave }\end{array}$ \\
\hline $\begin{array}{l}\text { Container, } \\
\text { Syringe, } \\
\text { Saline bag, } \\
\text { Disposable } \\
\text { syringe, } \\
\text { Bucket, Saline } \\
\text { set, Needle, X- } \\
\text { ray water, } \\
\text { Plastic bottle, } \\
\text { Ampoules, } \\
\text { Vials }\end{array}$ & $\begin{array}{l}\text { Clothes, Gauze, Cotton, } \\
\text { Mattress, Bandage, AID's } \\
\text { Patient's clothes, Rabies } \\
\text { patient's clothes, Paper, } \\
\text { Gloves, Saline bag, } \\
\text { Saline set, X-ray film, } \\
\text { Needle, Syringe, Blood } \\
\text { bag, Plaster of Paris, } \\
\text { Apron, Disposable syringe, } \\
\text { Plastic sputum pot, TB } \\
\text { slide }\end{array}$ & $\begin{array}{l}\text { Common waste, } \\
\text { Needle, } \\
\text { Syringe, Blood, } \\
\text { Lancets, } \\
\text { Specimen, } \\
\text { Collection pot, } \\
\text { Urine, stool, } \\
\text { Sputum, Saline } \\
\text { bag, Damaged } \\
\text { body parts, } \\
\text { Placenta, Slides, } \\
\text { Cotton etc }\end{array}$ & $\begin{array}{l}\text { Disposable syringe, Saline } \\
\text { bag set, Gloves, Needle, } \\
\text { Cotton, Gauze, Bandage, } \\
\text { Pad, Paper, Plastic, TB } \\
\text { slide, Sputum, Polythene, } \\
\text { Blood sample, Tissue } \\
\text { paper, Common wastes, } \\
\text { Dressing, Stool, Urine, } \\
\text { Broken Tube, Acid, Bottle, } \\
\text { Syringe etc }\end{array}$ & $\begin{array}{l}\text { Tips, } \\
\text { Reagents, } \\
\text { Chemicals, } \\
\text { Blood, } \\
\text { Urine, Stool, } \\
\text { Sputum, } \\
\text { Disposable } \\
\text { syringe, } \\
\text { Needle, } \\
\text { Gloves, } \\
\text { Slide, } \\
\text { Broken glass }\end{array}$ & $\begin{array}{l}\text { Cotton, Needle, } \\
\text { Syringe, TB } \\
\text { slides, Sputum } \\
\text { pot, Vials used for } \\
\text { sample collection } \\
\text { from the patient's. }\end{array}$ \\
\hline
\end{tabular}




\subsection{Risk associated with improper disposal of Medical waste}

The improper disposal of hospital waste in $\mathrm{CMCH}$ poses a high health risk to humans as well as the environment.

$>$ In warm temperature, sterile organic matter, like kitchen waste and pathological waste can become a potentially lethal source of toxic or disease-producing organisms.

$>$ The organic portion of medical waste also ferments and favors fly breeding

$>$ The garbage in refuse attracts rats and the produced pathogen may be conveyed to human being through flies and dusts.

$>$ Contamination of drinking water by leachate entering an aquifer, surface water.

$>$ Burning of waste at low temperatures or in open container results in release of toxic pollutants (e.g. dioxin) in the air.

$>$ Carcinogenic waste such as heavy metals, chemical solvents and preservatives pose serious human health risks not only to workers but to the general public as well.

Unprotected and insecure landfill may pose health hazard to the scavengers and inhabitants at the vicinity.

$>$ Pollutants from Medical waste (e.g. heavy metals and PCBs) are persistent in the environment.

$>$ With domestic animals being allowed to graze in open dumps, there is added risk of reintroducing pathogenic micro-organisms into the food chain.

$>$ Public nuisance (e.g. odors, scenic view, block the walkway, aesthetics, etc.).

$>$ Plastic bags, plastic containers, if not properly destroyed may contaminate the soil and also reduces the chance for water percolation into the soil during precipitation.

\section{Materials and Method:}

The methodology for this study includes empirical field observation and field level data collection through inventory, questionnaire survey and interviews in formal and non-formal ways. The presented study was carried out for a period of 3 months from July 2014 to September 2014. The work was divided into several sections to achieve precise result. In this study, samples were collected from 14 major wards of the hospital.

5.1 Field observations: Field observations were made at each location, using a checklist that focused on potential problems posed by disposal of Medical waste. Waste generation sites (ward, laboratory), laboratory (sample collection site, place of analysis, washing basin), and waste disposal sites (dustbin, dumping site, drainage system, wastewater flow) were observed. Current waste management system and the safety measures taken in the pathological laboratory and clinics were also observed.

5.2 Interview: Interviews were conducted with people involved in providing medical services and handling and disposing medical waste. Directors or divisional heads of different wards, doctors and nurses, laboratory technicians, cleaners, and garbage dwellers (tokai) were interviewed. Generally questions were geared towards the basic understanding of the respondents.

5.3 Laboratory analysis: Wastewater and solid waste from the drainage and disposal sites were collected for pathological (microbial) analysis of E.coli count, occurrence of Salmonella spp. and Vibrio cholera respectively.

\section{Results and Discussion}

On the basis of the functions of the wards, several types of wastes were found which could be classified as follows-The sharps included syringes and needles, ampoules and vials, saline bags and infusion sets. It was counted in number. The waste generation rate of one ward to another ward is different. The difference is because of the characteristics of each ward. Each ward requires a different type of diagnosis and treatment. Some diagnosis and treatment methods produce more waste than others. From the observation, highest disposal of syringes and needles, Saline bags with infusion sets and Ampoules \& vials was recorded in the ward designated Orthopaedic surgery about 4/patients/day, Radiotherapy ward about 3.09/patients/day and Paediatric Surgery ward was about 5.47/ patients /day respectively. On the other hand lowest disposal of syringes and needles, Saline bags with infusion sets and Ampoules \& vials was recorded postnatal ward about.18/ patients /day; Skin and STD ward .15/ patients /day and Ampoules \& vials about Postnatal ward .18/ patients /day respectively. 
Table 4. Waste generation rate of each ward

\begin{tabular}{|c|c|c|c|c|c|c|c|c|c|}
\hline \multirow[t]{2}{*}{$\begin{array}{l}\text { Serial } \\
\text { No. }\end{array}$} & \multirow[t]{2}{*}{ Name of the ward } & \multirow[t]{2}{*}{$\begin{array}{l}\text { No. of } \\
\text { patients/day }\end{array}$} & \multicolumn{2}{|c|}{$\begin{array}{l}\text { Saline bags with } \\
\text { infusion sets no. }\end{array}$} & \multicolumn{2}{|c|}{$\begin{array}{l}\text { Needles \& Syringes } \\
\text { no. }\end{array}$} & \multicolumn{2}{|c|}{$\begin{array}{l}\text { Ampoules \& vials } \\
\text { no. }\end{array}$} & \multirow{2}{*}{$\begin{array}{l}\text { Total } \\
\text { waste } \\
\text { (no.)/day }\end{array}$} \\
\hline & & & $\begin{array}{l}\text { ward/d } \\
\text { ay }\end{array}$ & $\begin{array}{l}\text { Patients/d } \\
\text { ay }\end{array}$ & $\begin{array}{l}\text { ward/d } \\
\text { ay }\end{array}$ & $\begin{array}{l}\text { Patients/d } \\
\text { ay }\end{array}$ & $\begin{array}{l}\text { ward/ } \\
\text { day }\end{array}$ & $\begin{array}{l}\text { Patients/d } \\
\text { ay }\end{array}$ & \\
\hline 1 & Skin and STD & 13 & 2 & .15 & 17 & 1.3 & 4 & .30 & 23 \\
\hline 2 & Radiotherapy & 21 & 65 & 3.09 & 86 & 4.09 & 112 & 5.34 & 263 \\
\hline 3 & Paediatric Surgery & 75 & 140 & 1.87 & 350 & 4.67 & 410 & 5.47 & 900 \\
\hline 4 & Paediatric Medicine & 114 & 93 & .81 & 315 & 2.77 & 356 & 3.12 & 764 \\
\hline 5 & Nephrology & 26 & 38 & 1.47 & 68 & 2.61 & 121 & 4.65 & 227 \\
\hline 6 & Surgery Unit-II & 114 & 117 & 1.02 & 310 & 2.72 & 340 & 2.99 & 767 \\
\hline 7 & Orthopaedic Surgery & 153 & 48 & .31 & 606 & 3.97 & 641 & 4.19 & 1448 \\
\hline 8 & Surgery Unit-III & 97 & 101 & 1.04 & 285 & 2.93 & 298 & 3.07 & 684 \\
\hline 9 & Neuro Surgery & 145 & 71 & .49 & 422 & 2.91 & 456 & 3.14 & 949 \\
\hline 10 & Gynae & 119 & 20 & .17 & 124 & 1.04 & 65 & .54 & 209 \\
\hline 11 & Surgery unit-1 & 88 & 145 & 1.65 & 310 & 3.52 & 358 & 4.07 & 813 \\
\hline 12 & Antenatal \& Labor & 104 & 140 & 1.34 & 344 & 3.30 & 321 & 3.08 & 805 \\
\hline 13 & Postnatal ward & 138 & 67 & .49 & 25 & .18 & 25 & .18 & 117 \\
\hline 14 & Burn unit & 27 & 39 & 1.45 & 104 & 3.86 & 30 & 1.11 & 173 \\
\hline
\end{tabular}

Percentage of ampoules and vials in total sharp was about $45.08 \%$ which occupied the larger portion of the total sharps, syringe and needles occupied about $42.20 \%$, infusion sets with saline bags occupied about $10.71 \%$ and about $2.01 \%$ pathological waste. All of these ampoules are disposed with the residue of different drugs.

Few selected pathogens were tested from collected hospital waste. These were Salmonella, Shigella, Mycobacteria, and Amoeba (Table 5). Samples were collected from several sources including dustbins (where hospital wastes were dumped), wastewater from hospital drains, and laboratory basins.

Table 5. Pathogens (number per gm in solid sample and per $100 \mathrm{ml}$ in liquid) in hospital waste analyzed from different sources

\begin{tabular}{|l|l|l|l|l|}
\hline $\begin{array}{l}\text { Source of } \\
\text { waste sample }\end{array}$ & $\begin{array}{l}\text { Salmonella/ } \\
\mathbf{1 0 0 m l} \text { or gm }\end{array}$ & $\begin{array}{l}\text { Shigella/ 100ml } \\
\text { or gm }\end{array}$ & $\begin{array}{l}\text { Mycobacteria/ } \\
\mathbf{1 0 0 m l} \text { or } \mathbf{g m}\end{array}$ & $\begin{array}{l}\text { Amoeba/ 100ml } \\
\text { or gm }\end{array}$ \\
\hline Dustbin & $2.3 \times 10$ & $5.2 \times 10$ & $2.4 \times 10$ & $2.8 \times 10$ \\
\hline Basin water & $2.4 \times 10$ & $1.3 \times 10$ & $1.2 \times 10$ & 2.5 \\
\hline Soil & $3.4 \times 10$ & $6.2 \times 10$ & $2.4 \times 10$ & $2.3 \times 10$ \\
\hline Drain Water & $5.4 \times 10$ & $1.4 \times 10$ & 6 & 4 \\
\hline solid & $2.2 \times 10$ & $2.4 \times 10$ & $4.2 \times 10$ & $2.5 \times 10$ \\
\hline
\end{tabular}

Laboratory analysis showed improper disposal of Hospital waste and severe contamination of these infectious wastes to the environment. Laboratory analysis shows high levels of contamination from infectious wastes at various sources in the environment (Table 5). Children, adults, and animals all have the potential to come into contact with these wastes that may pose severe health risks to them.

A total of 80 respondents from the $\mathrm{CMCH}$ were interviewed for this study. The respondents were selected from all the Wards $(n=60)$, Operation Theatres $(n=11)$ and outdoor, emergency and other departments $(n=9)$. Among the interviewees of the $\mathrm{CMCH}$, respondents $60(80.33 \%)$ were female and 20 $(19.67 \%)$ were male respondents. It is noted here that all the female respondents were nurses, and the rest were doctors, medical technicians, and cleaners. The average age of the respondents was about 42 years and the average length of service was about 20 years. About $88.88 \%$ respondents believed that the present disposal system is quite unsafe and hazardous for human health as well as environment.

\section{Recommendation}

Based on the findings of this study, the following recommendations are made to improve the medical waste management in Chittagong Medical College Hospital (CMCH).

1. Raise awareness and education on medical waste issues,

2. It is essential to treat the infectious waste before dumping them into the Chittagong City Corporation (CCC) dumping grounds.

3. Arrangement of training regarding this issue could minimize the health risk.

4. Non-infectious and domestic type of waste should be collected in high-density polyethylene bags labeled with a bio-hazardous infectious materials symbol in specific bins (Patil and Pokhrel, 2004).

5. Remedial measures with the installation of a commercial environment friendly incinerator in the $\mathrm{CMCH}$ are suggested.

6. Proper waste management strategy is needed to ensure health and environmental safety from medical waste, 
7. Segregation of medical waste should be done at the point of generation. Different coloured bags should be used for collection of hazardous and non-hazardous waste,

8. Safety protection must be taken in handling hazardous waste. Gloves, masks, aprons, etc. must be used during handling of medical waste,

9. Hazardous medical waste may be collected from different hospitals and treated centrally. Methods of treatment should be selected carefully,

10. To minimize the generation of medical waste, good housekeeping, replacement of chemicals, etc. may be adopted,

11. Training programme on safe handling of medical waste can be organised for medical staff,

12. Government should promulgate and implement laws and regulations regarding medical waste management

\section{Conclusion}

From this investigation it is found that wastes from hospital such as placenta, syringes, needles, sputum pots, chemical agents are all potential areas of concern for hospital waste management. In most cases wastes were thrown into municipal bins, without regard to the harmful effects they may pose to human health and the environment. Various methods were used by the $\mathrm{CMCH}$ to dispose off waste such as burning, burial, and direct through to the municipal dustbin. $\mathrm{CMCH}$ re-used syringes and other things and sold their waste. On the other hand Sharps, Pathological wastes chemicals are carelessly drained to the public places. And these are degrading the health and hygiene of the surrounding environment. That's why waste characterization, assessment and management are must for the $\mathrm{CMCH}$. This will also be a model for the all types of hospitals in the country. Bacterial load in the wastes and soil showed a worse scenario of environmental pollution caused by medical waste and it is evident that medical wastes are the reservoir of microorganisms, which acts as transmission vehicle of many diseases. A small amount of budgetary provisions are allocated to manage their generated waste systematically. So we should raising awareness, improving waste handling and disposal system, and implementing laws and regulations for ensuring healthy environment.

\section{Reference:}

[1]. Rashid, S. (1996), Medical waste disposal in Dhaka city: A survey. North-South University. Bangladesh, Dhaka.

[2]. Kazi, N.M. 1997. Waste Management in Dhaka. Bangladesh Environmental Newsletter, vol.8, No.4. Bangladesh Center for Advanced Studies (BCAS), Dhaka, Bangladesh.

[3]. Akter, N., N. M. Kazi, A. M. R. Chowdhury (1999). Environmental Investigation of Medical Waste Management System in Bangldesh With Special Reference to Dhaka City. BRAC, Research and Evaluation Division, 75 Mohakhali, Dhaka 1212, Bangladesh.

[4]. Burke, E.L.J. Environment Health 1994, 56 (9), 11-14).

[5]. Lawson A. 2010. UN tackles Dhaka's medical waste.

[6]. World Bank, (2009), Health Facility Waste Management Study in Bangladesh. Dhaka.

[7]. WHO. 2010, Basic Steps in the Preparation of Health Care Waste Management Plans for Health Care Establishments.

[8]. Waste concern, (2011), Principles of Medical Waste Management in Dhaka city.

[9]. National Environmental Research Institute (1997). Instructions for handling and administering of cytostatics, Stockholm.

[10]. Chih-Shan \& Fu-Tien (1993). Guidelines for the safe handling of hazardous pharmaceuticals. China.

[11]. Askarian M; Vakili M; and Kabir G. 2004. Results of a hospital waste survey in private hospitals in Fars province, Iran. Waste management, 24 (2004): 347-352.

[12]. Mato RRAM and Kaseva ME. 1999. Critical review of industrial and medical waste practices in Dar es Salaam City. Resources, Conservation and Recycling, 25 (1999): 271-287.

[13]. Patil GV and Pokhrel K. 2004. Biomedical solid waste management in an Indian hospital: a case study.

[14]. Ahmed A. 2000. Hospital Waste Management: Problems and Strategic Solutions. Dhaka: Independent University, Bangladesh $(I U B)$.

[15]. BCAS, (1997), the BCAS in collaboration with Asia Foundation undertook a study on "Hospital Environmental Management" with the aiming of investigation and improvement of safe handling and disposal of hospital waste in the country. 